\title{
The construct of career success: measurement issues and an empirical example
}

\author{
Andrea E. Abele $\cdot$ Daniel Spurk $\cdot$ Judith Volmer
}

Published online: 7 July 2010

(C) Institut für Arbeitsmarkt- und Berufsforschung 2010

\begin{abstract}
The aim of the present paper is twofold. We first give an overview of the multi-faceted construct of career success with its "objective" (real attainments) and "subjective" (perceived attainments) components and with the different methodologies measuring them ("subjectivist" vs. "objectivist" approaches). We also discuss the relationship between the different components of career success as revealed in the literature. Our second aim is to show that the interrelationship between the different facets of career success varies with the employment context. We analyze subjective and objective career success measures collected from professionals working either in the private sector, in the public sector, or that are self-employed. Our findings show that objective success and subjective success are more closely related in the private and self-employment sectors than in the public sector. Moreover, the interrelationship between objective and subjective success varies with the specific subjective success measure chosen. It is stronger for an "other-referent" subjective success measure than for a "self-referent" subjective success measure. Conclusions regarding the measurement of career success as well as regarding the relevance of subjective success for studying occupational careers are drawn.
\end{abstract}

Keywords Objective vs. subjective career success . Self-referent vs. other-referent subjective success . Interplay between objective and subjective success in different fields of employment

\section{JEL classification Z}

A. E. Abele $(\varangle) \cdot$ D. Spurk $\cdot$ J. Volmer University of Erlangen-Nuremberg, Chair of Social Psychology, Bismarckstr. 6, 91054 Erlangen, Germany

e-mail: abele@phil.uni-erlangen.de
Das Konstrukt des Berufserfolgs: Messmethoden und ein empirisches Beispiel

Zusammenfassung Der Beitrag verfolgt zwei Zielsetzungen. Wir geben zuerst einen Überblick über das facettenreiche Konstrukt des Berufserfolgs mit seiner "objektiven“ (tatsächliche Errungenschaften) und seiner „subjektiven“ (wahrgenommene Errungenschaften) Konnotation sowie mit verschiedenen Möglichkeiten der Messung (,subjektivistische“ vs. „objektivistische“ Ansätze). Außerdem diskutieren wir den empirischen Zusammenhang zwischen den verschiedenen Komponenten. Unser zweites Ziel ist es, zu zeigen, dass der Zusammenhang zwischen subjektivem und objektivem Berufserfolg kontextspezifisch variiert. Wir analysieren Daten einer großen Stichprobe von Akademikern, die in der Privatwirtschaft, im öffentlichen Dienst oder selbständig/freiberuflich arbeiten. Es zeigt sich, dass der Zusammenhang zwischen subjektivem und objektivem Berufserfolg im öffentlichen Dienst kleiner ist als bei den beiden anderen Beschäftigungsformen. Außerdem variiert der Zusammenhang je nach Art der Messung von subjektivem Erfolg. Objektiver Erfolg und subjektiver Erfolg als Vergleichsurteil korrelieren stärker als objektiver Erfolg und subjektiver Erfolg als Zufriedenheitsurteil. Folgerungen für die Messung von Berufserfolg und für die Bedeutung subjektiven Erfolgs in der Berufslaufbahn werden abgeleitet.

\section{Introduction}

Imagine that somebody asks you the following question: "How successful has your occupational career been so far?" Would it be easy for you to answer this question or would you need considerable time to think about it? Which crite- 
ria would you apply? Would you refer to your bank-account, would you refer to your reputation among colleagues, would you refer to an ongoing project? Would you give a simple successful vs. unsuccessful answer or would you differentiate between several criteria? Which standard(s) of comparison would you use? Irrespective of how these questions will be answered people are no doubt concerned about their career success, they want to be successful and they want to feel successful. The meaning of career success is, however, not easy to grasp.

The aim of the present paper is twofold. We first give an overview of the construct of career success and of the different meanings career success can have. We also give an overview of the interrelationship of different facets of career success as revealed in the literature. The second aim of the present paper is to present an empirical example for our proposition that career success is a contextualized phenomenon. We propose and show that the interrelationship between objective attainments like money or status/position and the subjective experience of career success differs between different occupational contexts and between different measures of subjective success.

\section{What is career success?}

Career success has long been of interest not only to individuals engaged in a career, but also to career researchers and to practitioners in the field (Gunz and Heslin 2005; Hughes 1937; Parsons 1909; Super 1990). Career researchers want to analyze the determinants of more or less successful careers, practitioners want to know how to advise people in their careers; and employees want to be successful because career success is one main goal in many people's lives and career success can be a powerful motivator for further positive outcomes like performance, well-being, or further success. But what is career success?

"Career" is both a descriptive term for an individual's - occupational - life course and the changes taking place in this occupational life course such as job changes, times of unemployment, relocations, promotions, times of further education, and so forth (Super 1990); and it is an evaluative term, meaning upward development, and climbing up the career ladder (German: "Karriere"). A third meaning of career refers to how individuals make sense of their occupational development (Arthur et al. 2005; Hall 2002; Arthur and Rousseau 1996; Briscoe and Hall 2006; De Vos and Soens 2008).

The term "success" is also both descriptive for progress, and evaluative for a positive evaluation of outcomes or progress. Most important, success is also a subjective construction. People need standards against which they can evaluate an outcome (Schwarz 1999) and different people will use different standards of evaluation. The composite term of "career success" has been defined as: "The real or perceived achievements individuals have accumulated as a result of their work experiences" (Judge et al. 1999a, p. 621).

This distinction between description and evaluation as well as between "real" vs. "perceived" achievements is the basis for distinguishing between "objective" and "subjective" career success (Hughes 1937; Heslin 2005; Ng et al. 2005; Sullivan and Baruch 2009). Hughes defined objective career success as directly observable, measurable, and verifiable by an impartial third party. Subjective career success, in contrast, was defined by an individual's reactions to his or her unfolding career experiences (Hughes 1937; Heslin 2005). It is widely acknowledged that both components are essential in career success research. We will now turn to the peculiarities of measuring "objective" and "subjective" career success.

Salary, salary growth, status, and promotions are the most widely used indicators of objective career success, because they can be directly measured and verified (Abele and Spurk 2009a,b; Heslin 2005; Judge et al. 1995; Ng et al. 2005; Spurk and Abele, in press), and they can be both externally assessed by for example work records and by asking the employees (Dette et al. 2004). Furthermore, pay, status, and promotions are important to individuals on a very basic level of need fulfillment (Nicholson and De Waal-Andrews 2005). They reflect societal norms regarding the "success" of a career, and they are "objective" in the sense of being socially shared. Finally, objective attainments like pay or hierarchical status are proxies for performance. Scholars and practitioners are interested in finding determinants that are valid for predicting an individual's career success also with respect to the gains the organization he or she is working in will have from this employee. The analysis of the determinants of pay and pay development allows some conclusions on the determinants of performance over time.

However, these indicators have also been criticized for several reasons. First, indicators of objective career success have to be adapted to changing organizational and labormarket conditions. The hierarchical career with clear-cut career steps and easily identifiable hierarchical positions is not the most frequent model any more and objective indicators such as status and promotions have to be reconsidered. Second, salary is differentially suited as an indicator of objective success in different fields of employment (Dette et al. 2004). It can, for instance, barely be negotiated in state employments. Third, salary depends on the employer. The same occupational performance may be paid differently by different employers. Fourth, objective career success criteria have often been developed with respect to employees with high potential like professionals, managers, and so called "white- 
collar" workers. Objective success criteria with respect to less educated "blue-collar" workers are less well developed. These might relate to, for instance, being employed or not, being paid such that one can live on it or not, having the chance to leave a temporary employment in favor of a permanent employment, etc. Finally, it may be generally questioned whether salary is an indicator of objective success or whether performance-related achievements are more suited as measures of objective success.

Heslin (2003, 2005; see also Turban and Dougherty 1994) was one of the first to argue that two kinds of subjective career success evaluations should be distinguished according to the standard of comparison applied, namely whether success is evaluated against a "self-referent" standard, or against a so-called "other-referent" standard.

In self-referent subjective success an individual compares his/her career relative to personal standards and aspirations. Most often job or career satisfaction are taken as criteria (Abele and Spurk 2009a; Boehm and Lyubomirsky 2008; Boudreau et al. 2001; Bozionelos 2004; Judge et al. 1995; $\mathrm{Ng}$ et al. 2005; Seibert et al. 2001). These satisfaction judgments are self-referent, because satisfaction is rated with respect to the self. Job satisfaction refers to satisfaction with one's working conditions and career satisfaction is related to the evaluation of one's occupational development until now. Whereas satisfaction is no doubt an important facet of subjective success, other-referent measures are also important.

In other-referent subjective success an individual compares his/her career relative to a social standard, for instance a reference group, a reference person, or a social norm. According to social comparison theory (Festinger 1954), many situations in which evaluative judgments have to be made do not provide objective standards of evaluation. There are, for instance, barely objective standards for evaluating the quality of a movie, and in forming their judgment people will not only consider their own impression but others' judgments as well. In such situations people rely on social comparisons and take others as a standard of comparison. Social comparisons are frequent in situations with no or only ambiguous objective standards of evaluation. Regarding the evaluation of one's career success there are many standards of comparison conceivable. Individuals will possibly consider what relevant others have achieved and this comparison will influence judgments of their own achievements. Heslin (2003) found that more than two-thirds of his respondents used social comparisons in determining their subjective success.

\section{Subjectivist approaches to the assessment of career success}

Even if it is not central to the present reasoning we will nevertheless shortly cover the issue of measuring subjective suc- cess. Scholars have argued that taking standard measures of - subjective - career success is an objectivist approach that does not consider its social constructivist character (Arthur et al. 2005; Dries et al. 2008; Savickas 2005). A subjectivist approach to career success, in contrast, considers an individual's subjective construction of success. Career success then is what the individual understands as career success. This understanding differs between people, between employments, between age groups, and between cultures. Subjective constructions of career success may also be dynamic and change over time as well as with career stages. Dries et al. (2008), for instance, found that their participants' subjective conceptualizations of career success could be depicted in a two-dimensional space with the horizontal dimension labeled affect versus achievement and the vertical dimension labeled intra-personal versus inter-personal. Nine regions are embedded in this structure. They denote different subjective meanings of career success like performance, advancement, self-development, creativity, security, satisfaction, recognition, cooperation, and contribution. It should be noted, however, that objectivist versus subjectivist approaches do not preclude one another. A research could, for instance, start with an analysis of the study of participants' subjective constructions of career success and could then proceed to operationalize these constructions by means of questionnaire items which later participants can answer.

\section{The interrelationship between objective and subjective career success}

So far, we have discussed different meanings of career success and have argued that for a comprehensive understanding of career success both objective and subjective components should be measured. We will now analyze how these components are empirically related. A number of studies report positive correlations between objective career success and career satisfaction (Judge et al. 1995; Martins et al. 2002; Richardsen et al. 1997; Raabe et al. 2007; Schneer and Reitman 1993, 1997; Wayne et al. 1999). Some studies show positive correlations between objective success and other-referent subjective success (Abele and Wiese 2008; Kirchmeyer 1998; Turban and Dougherty 1994). However, findings on the relationship between objective career success and self-referent success, more specifically job satisfaction, are equivocal (no relationship: Judge et al. 1995; Richardsen et al. 1997; positive relationship: Judge et al. 1999b; Cable and DeRue 2002). A recent meta-analysis by Dette et al. (2004) was based on 25 published studies that had reported correlations between objective and subjective success measures. It revealed an estimated mean correlation of $\rho_{\text {est }}=0.28$; this correlation is significantly different from zero. It is, however, relatively small. Furthermore, this meta- 
analysis revealed a large heterogeneity of results suggesting that there are further factors influencing the relationship between objective and subjective success. $\mathrm{Ng}$ et al. (2005) also reported meta-analytic correlations of objective and subjective career success not higher than 0.30.

What do these positive but relatively small and heterogeneous associations between objective and subjective career success measures mean? On the one hand, they mean that - albeit related - subjective and objective career successes are clearly distinct. On the other hand, they mean that the relationship between subjective and objective career success varies; hence, there are a number of moderators to be taken into account. We are not aware of any research that systematically tested such moderators. Therefore, our following empirical example will be concerned with one important variable that may moderate the relationship between subjective and objective career success, namely the employment context.

\section{An empirical example}

Careers are managed by individuals engaged in a career and they are embedded in specific employment contexts. These contexts differ in many respects, for instance, size and structure of the organization, salary and promotion regulations, job design, leadership, specific tasks, to mention just a few. One extreme could, for instance, be the self-employed lawyer who runs a "one-person" office. This person is highly autonomous in deciding how and how much he or she wants to work. Hence, this person's objective career success in terms of income is highly contingent on his/her performance. We would expect that in the case of self-employed persons the correlation of objective success and subjective success would be relatively high. Another extreme could, for instance, be the state-employed teacher. This person's salary is much less contingent on his/her performance. Both an enthusiastic teacher who advances the pupils' knowledge as much as possible and a teacher who just does a routine job will by and large receive the same salary, i.e., will not differ in objective success. In the case of state-employed persons we would expect a relatively low correlation between objective and subjective success.

Starting from these examples we will first study whether the kind of employment is a moderator for the objective career success-subjective career success relationship. We apply a widely accepted distinction between self-employed persons, private-company-employed persons (private sector), and state-employed persons (public sector) and we will take two standard measures of objective success, pay and status/position. We expect that kind of employment is a moderator of the interrelationship between objective and subjective career success. More specifically, we expect that the intercorrelation between objective and subjective career success should be smaller in the case of state-employed persons than in the case of self-employed or private-companyemployed persons.

Above we have argued that subjective career success has to be distinguished for self-referent and other-referent success. We have further reported findings that correlations between objective success and other-referent success are always positive, whereas the empirical correlation between objective success and self-referent success (job satisfaction) is equivocal. Our second research question therefore concerns the interrelationship of objective career success with self-referent vs. other-referent subjective success. We expect stronger correlations between other-referent subjective career success and objective career success than between self-referent subjective career success and objective career success. Besides the above-mentioned empirical findings we base this assumption on the following reasoning: Comparing own attainments with others' attainments needs a comparison standard that can be externally inferred, for instance salary or promotion. The assessment of one's own satisfaction, on the other hand, can be based on many standards, and salary is only one of them.

Regarding other-referent subjective success previous research asked participants to compare their career success relative to "your co-workers" and "the feelings of significant others" (Kirchmeyer 1998; Turban and Dougherty 1994). Heslin (2003) asked the same questions ("how satisfied are you with the advancement you have attained") both with respect to self-referent standards ("relative to my career aspirations") and with respect to other-referent standards ("relative to my career peers"). We will here assess comparisons with "former fellow students," "other people with a university degree," and "persons of my age group." Regarding selfreferent subjective success we will here assess both job satisfaction and career satisfaction.

We base our analyses on data gathered in a longitudinal study of professionals' career development. Findings have already been reported elsewhere (Abele 2003; Abele and Spurk 2009a,b; Abele and Wiese 2008) but the present analysis is the first one to study the interrelationship between different facets of career success in dependence on kind of employment. We chose a time of measurement at which our participants were employed for about 10 years.

\subsection{Method}

We tested our hypotheses with data collected in a prospective longitudinal study with a large sample of professionals who had graduated from a German university. Participants completed the first questionnaire shortly after they had passed their final exams. We will here be concerned with 
data from the fifth wave of measurement that was undertaken 10 years after the participants' graduation.

Participants and procedure The sample comprised 510 women and 715 men (mean age 37 years) with degrees in law (69 participants), medicine (196 participants), arts and humanities (118 participants), natural sciences (157 participants), economics (216 participants), engineering (235 participants), and teaching (234 participants). A drop-out analysis comparing participants who took part in wave five with the initial sample revealed that this wave five sample showed the same distribution of gender, study major, and grade point average as the initial one.

Measures We operationalized objective career success once by monthly salary before taxes (in 13 steps from "no salary", coded as 0; "less than EUR 500", coded as 0.5; "less than EUR 1,000", coded as 1; and then in equal steps to "less than EUR 10,000", coded as 10; and "more than EUR 10,000", coded as 11). We further operationalized objective career success by hierarchical position (permission to delegate work, $0=n o, 1=y e s$; project responsibility, $0=n o, 1=$ yes; official leadership position, $0=n o, 1=y e s$; summary score from 0 "low" to 3 "high").

We measured self-referent subjective career success with respect to satisfaction with one's job, and satisfaction with one's career. Overall job satisfaction ("All in all, how satisfied are you with your job at the moment?") was measured with one item. Participants based their responses on fivepoint rating scales $(1=$ not at all to $5=$ absolutely $)$. Career satisfaction was measured with a career satisfaction questionnaire (Greenhaus et al. 1990; five items, "I am satisfied with the success I have achieved in my career."). Participants answered the questions using five-point rating scales $(1=$ strongly disagree, $5=$ strongly agree $)$. The reliability of the scale is good, Cronbach's alpha $=0.84$.

We operationalized other-referent subjective career success with three items: a comparison with former fellow graduates ("Compared with your former fellow graduates, how successful do you think your career development has been so far?"), with other people with a university degree, and with people of the participant's age group. Participants based their responses on five-point rating scales $(1=$ less successful to $5=$ more successful). The reliability of the scale is good, Cronbach's alpha $=0.79$.

We also asked our participants to indicate their kind of employment (self-employed, state-employed, privatecompany-employed; unemployed; parental leave; multiple employments) and to indicate their weekly contractual working hours. For our further analyses we considered self-employed $(N=177)$, state-employed $(N=294)$, and private-company-employed participants $(N=541)$. The other participants (unemployed, parental leave, multiple employments; $N=213$ ) were not considered here. We also considered weekly working hours in our following analyses because these are highly correlated to salary and sometimes also to subjective success (Schneer and Reitman 1993).

\subsection{Results}

Intercorrelations Table 1 shows the means, standard deviations, and intercorrelations of the variables considered here both for the whole sample of 1,012 participants, and then separated by kind of employment. Salary and position are positively correlated with similar correlations across the three employment groups. The measures of other-referent subjective success are generally positively associated with objective success. The measures of self-referent success, however, are only partly related to objective success. The intercorrelations of the subjective success measures are generally positive.

Differences between the three employment groups We then compared the mean level of objective and subjective success between groups. The objective success parameters differed significantly between groups with the self-employed participants and the participants in the private sector earning more money (self-employed vs. public sector, $t[469]=7.37^{* * *}$; private vs. public sector $t[833]=12.58^{* * *}$; self-employed vs. private sector, $t<1)$ than the participants from the public sector, $F(2,1009)=60,91^{* * *}, \eta^{2}=0.11$. The position differed between all three groups, $F(2,1009)=74.05^{* * *}, \eta^{2}=0.13$, with self-employed being highest, participants from the private sector in the middle, and participants from the public sector lowest (self-employed vs. private sector, $t[716]=4.25^{* * *}$; self-employed vs. public sector, $t[469]=$ $10.87^{* * *}$; private vs. public sector, $\left.t[833]=9.70^{* * *}\right)$. In contrast, only one of the three subjective success measures differed between groups, other-referent success, $F(2,1009)=4.05^{*}, \eta^{2}=0.01$. Participants from the public sector felt less successful than self-employed participants, $t(469)=1.96^{*}$ and than participants from the private sector, $t(833)=2.93^{* *}$. Self-employed participants and participants from the private sector did not differ, $t<1$. Job satisfaction, $F(2,1009)=2.12, n s$, and career satisfaction, $F(2,1009)=2.34, n s$, did not differ between the three occupational groups. Fig. 1 graphically depicts these findings.

Interrelationship of objective career success and subjective success in the three groups We computed multiple correlations between one subjective success measure and the two objective success measures (salary, position) for the whole sample and for the three employment groups (Table 2).

Regarding the whole sample the multiple correlation of objective success with other-referent subjective success was high and positive, supporting previous findings on an overall positive relationship between these measures. The relation- 
Table 1 Means, standard deviations, and intercorrelations in the whole sample $(N=1,012)$ and the subsamples of self-employed $(N=177)$, private-company-employed $(N=541)$, and state-employed $(N=294)$ respondents

\begin{tabular}{|c|c|c|c|c|c|c|c|}
\hline & \multirow[t]{2}{*}{$M$} & \multirow[t]{2}{*}{$S D$} & \multicolumn{5}{|c|}{ Intercorrelations } \\
\hline & & & 2 & 3 & 4 & 5 & 6 \\
\hline \multicolumn{8}{|c|}{ 1. Obj. success (salary) } \\
\hline All & 6.35 & 2.31 & $0.47^{* * *}$ & $0.12^{* * *}$ & $0.30^{* * *}$ & $0.47^{* * *}$ & $0.52^{* * *}$ \\
\hline Self-employed & 6.90 & 3.45 & $0.42^{* * *}$ & $0.32^{* * *}$ & $0.46^{* * *}$ & $0.58^{* * *}$ & $0.49^{* * *}$ \\
\hline Private sector & 6.82 & 1.91 & $0.39^{* * *}$ & $0.14^{* *}$ & $0.32^{* * *}$ & $0.40^{* * *}$ & $0.49^{* * *}$ \\
\hline Public sector & 5.17 & 1.61 & $0.52^{* * *}$ & $-0.15^{* *}$ & $0.04 n s$ & $0.19^{* *}$ & $0.56^{* * *}$ \\
\hline \multicolumn{8}{|c|}{ 2. Obj. success (position) } \\
\hline All & 1.62 & 1.22 & & $0.05 n s$ & $0.18^{* * *}$ & $0.32^{* * *}$ & $0.30^{* * *}$ \\
\hline Self-employed & 2.20 & 1.14 & & $0.15 n s$ & $0.27^{* * *}$ & $0.31^{* * *}$ & $0.38^{* * *}$ \\
\hline Private sector & 1.79 & 1.11 & & $0.07 n s$ & $0.23^{* * *}$ & $0.36^{* * *}$ & $0.16^{* *}$ \\
\hline Public sector & 0.98 & 1.19 & & $-0.06 n s$ & $0.02 n s$ & $0.25^{* * *}$ & $0.28^{* * *}$ \\
\hline \multicolumn{8}{|c|}{ 3. Self-referent subj. success (job satisfaction) } \\
\hline All & 3.72 & 0.75 & & & $0.56^{* * *}$ & $0.34^{* * *}$ & $-0.01 n s$ \\
\hline Self-employed & 3.82 & 0.79 & & & $0.68^{* * *}$ & $0.55^{* * *}$ & $0.09 n s$ \\
\hline Private sector & 3.69 & 0.71 & & & $0.52^{* * *}$ & $0.30^{* * *}$ & $-0.05 n s$ \\
\hline Public sector & 3.69 & 0.78 & & & $0.53^{* * *}$ & $0.25^{* * *}$ & $-0.10 n s$ \\
\hline \multicolumn{8}{|c|}{ 4. Self-referent subj. success (career satisfaction) } \\
\hline All & 3.62 & 0.73 & & & & $0.56^{* * *}$ & $0.12^{* * *}$ \\
\hline Self-employed & 3.72 & 0.84 & & & & $0.70^{* * *}$ & $0.22^{* *}$ \\
\hline Private sector & 3.62 & 0.70 & & & & $0.54^{* * *}$ & $0.05 n s$ \\
\hline Public sector & 3.57 & 0.71 & & & & $0.47^{* * *}$ & $0.08 n s$ \\
\hline \multicolumn{8}{|c|}{ 5. Other-ref. subj. success } \\
\hline All & 3.46 & 0.70 & & & & & $0.12^{* * *}$ \\
\hline Self-employed & 3.50 & 0.90 & & & & & $0.30^{* * *}$ \\
\hline Private sector & 3.50 & 0.66 & & & & & $0.15^{* *}$ \\
\hline Public sector & 3.36 & 0.63 & & & & & $0.14^{*}$ \\
\hline \multicolumn{8}{|l|}{ 6. Work hours } \\
\hline All & 37.82 & 7.84 & & & & & \\
\hline Self-employed & 40.48 & 11.97 & & & & & \\
\hline Private sector & 38.14 & 5.69 & & & & & \\
\hline Public sector & 35.62 & 7.54 & & & & & \\
\hline
\end{tabular}

*** $p<0.001 ;{ }^{* *} p<0.01$

Table 2 Multiple correlations between objective success (salary, position) and the three subjective success measures in the whole sample $(N=1,012)$ and the subsamples of self-employed $(N=177)$, private-company-employed $(N=541)$, and state-employed $(N=294)$ respondents

\begin{tabular}{lllll}
\hline & All & Self-employed & Private sector & Public sector \\
\hline$R_{\text {object. - job satisfaction }}$ & $0.15^{* * *}$ & $0.32^{* * *}$ & $0.14^{* * *}$ & $0.15^{* * *}$ \\
$R_{\text {object. - career satisfaction }}$ & $0.31^{* * *}$ & $0.47^{* * *}$ & $0.34^{* * *}$ & $0.04^{* * *}$ \\
$R_{\text {object. - other-referent judgment }}$ & $0.48^{* * *}$ & $0.59^{* * *}$ & $0.53^{* * *}$ & $0.26^{* * *}$ \\
\hline
\end{tabular}

*** $p<0.001$

ship was higher than the one between career satisfaction and objective success, $Z=6.39^{* * *}$ (Steiger's $Z$; Steiger 1980; for applications using multiple correlations see also Tabachnik and Fidell 2001), and higher than the one between job satisfaction and objective success, $Z=9.32^{* * *}$; finally the relationship between career satisfaction and objective suc- cess was higher than the one between job satisfaction and objective success, $Z=5.59^{* * *}$.

In accord with our assumption, the relationship between objective success and other-referent success was higher for the self-employed and private-company employed participants than for the participants working in the public 
Fig. 1 Objective and subjective success in three groups of professionals (mean values $z$-transformed)

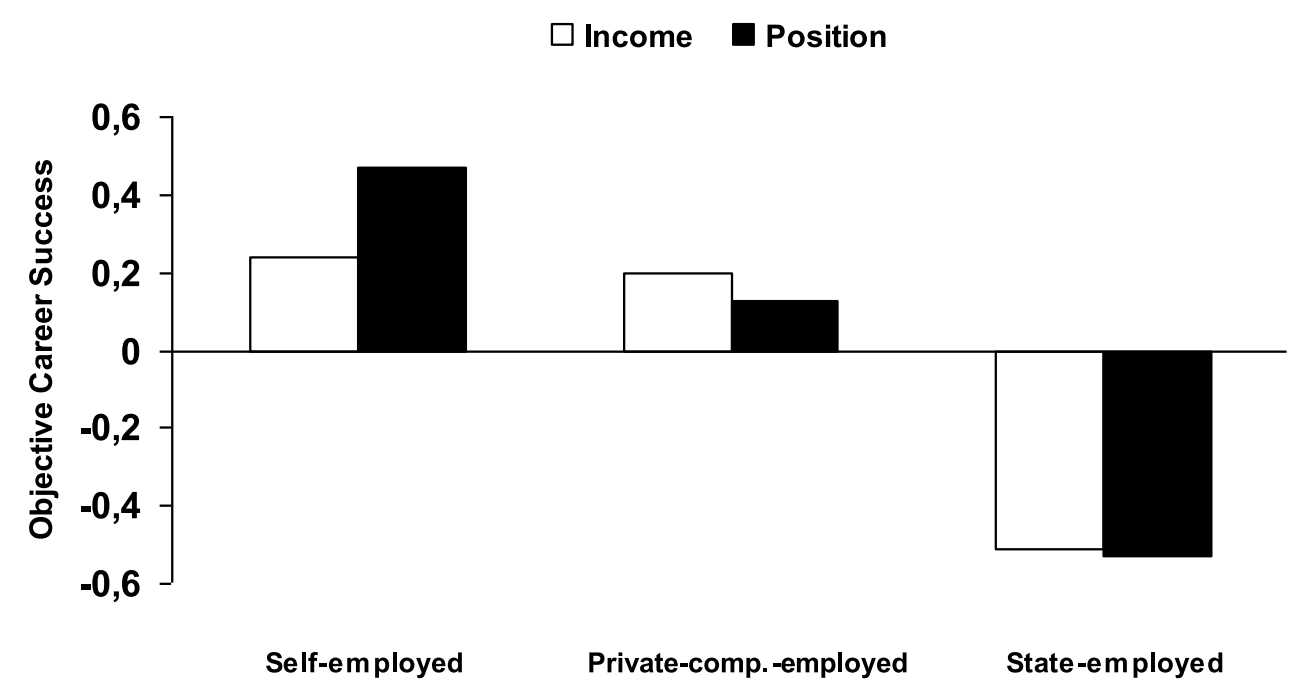

$\square$ Job satisfaction

Career satisfaction

$\square$ Other-referent success

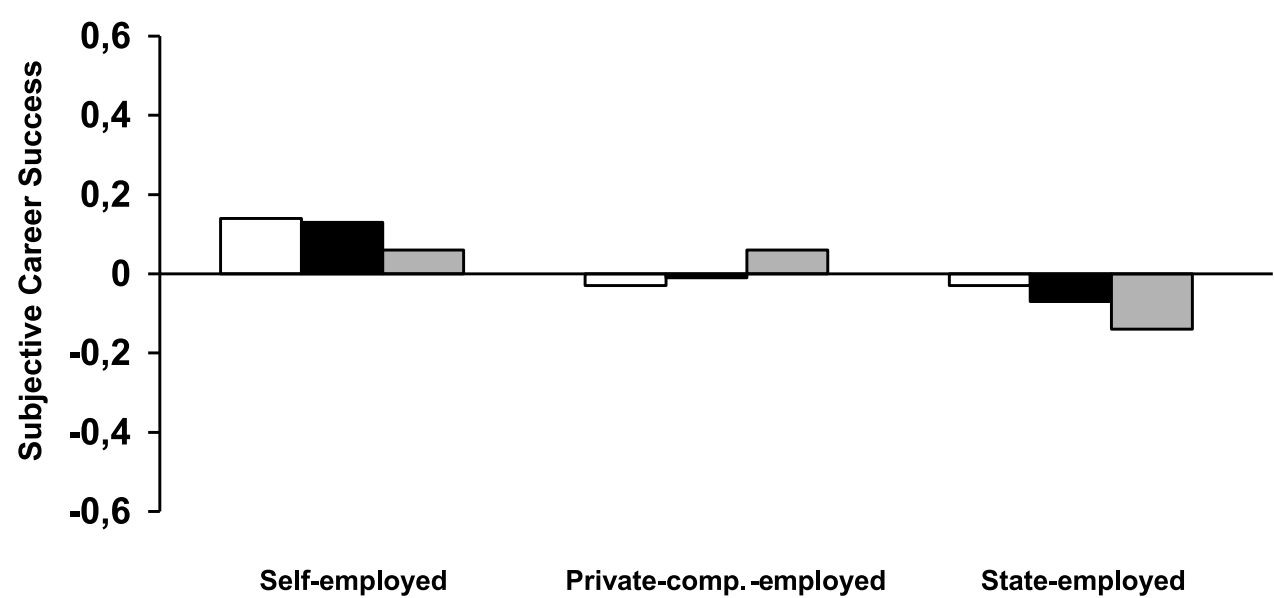

sector ( $Z$-values, Olkin and Finn 1995: self-employedpublic: $Z=1.89^{*}$; private-public: $Z=2.14^{*}$; self-employed-private: $Z<1$ ).

Regarding objective success and career satisfaction the multiple correlation again was higher for self-employed participants than for participants from the public sector, $Z=2.00^{*}$; participants from the private sector also showed a stronger relationship between these measures than those from the public sector, $Z=2.34^{* *}$. Self-employed participants and participants from the private sector did not differ, $Z<1$.

Finally, the multiple correlations between objective success and job satisfaction did not differ significantly between the three employment groups, $Z_{s}<1.14$.

Interrelationship of objective and subjective success considering salary three years earlier It might be argued that subjective success judgments cover a longer time span than objective success measures because the former are based on one's career until a particular point in time, whereas the latter assess present salary and present position. In our final analysis we therefore computed the above multiple correlations once more and now also included salary and position of the fourth wave of the study (same measure as at time 5). Since these results were very similar to the ones presented in Table 2, we will not report them in detail herein.

\subsection{Discussion}

Summarizing, in accord with our first assumption we found that the interrelationship of objective and subjective career success was moderated by kind of employment. The strongest interrelationship existed for self-employed partic- 
ipants and the weakest one was found for state-employed participants.

The interrelationship of objective and subjective success measures in the case of self-employed and private-companyemployed participants was considerably higher than the one reported in the above meta-analyses (Dette et al. 2004; $\mathrm{Ng}$ et al. 2005), whereas the respective multiple correlation for state-employed persons paralleled the above mean correlation. Salary and position seem to be significant standards for evaluating one's career success in employments in which people's objective attainments are highly contingent on their behavior, i.e., how much they work and how good they perform. This contingency is lower in the public sector.

We also found considerable differences in salary and position between the three groups compared herein. Participants from the public sector were always lowest. In contrast to objective success, differences in subjective success were much smaller, especially if self-referent subjective success was analyzed. This finding suggests that participants from the public sector based their job- and career satisfaction on other sources than money and position.

Supporting our second assumption, the relationship of other-referent subjective success and objective success is stronger than the one of self-referent subjective success and objective success. Job satisfaction is least related to objective success.

Finally, it should be stressed that these findings also hold when previous objective success data (salary and position three years before) were also considered. Hence, we are confident that the results are not just a "one-moment-shot" but reflect the relationship between objective and subjective success in a career phase when participants already have considerable career experience (about 10 years of employment).

\section{Conclusions}

The present paper was meant to give an overview of the definition and measurement of career success and also to show that the interrelationship between different measures of objective and subjective career success is moderated by the specific employment a person is in.

Objective success Our data showed that even though our sample was highly homogeneous with respect to educational background (all participants were professionals with a university degree) salary and position varied with the occupational context. An excellent teacher barely earns as much as an excellent self-employed medical doctor, an excellent self-employed lawyer only then has a high salary when he/she works hard and when there are enough clients to work for. A medical doctor in a state hospital usually earns less than a medical doctor doing the same job in a private hospital. This suggests that even though salary (similarly: status/position) is no doubt an "objective" indicator of career success it nevertheless has to be considered with respect to the specific occupational context in order to be a valid indicator of an individual's "objective" career success.

Subjective success Regarding subjective success the distinction between self-referent and other-referent subjective success is important. Other-referent subjective success evaluations are often made, and people draw some of their satisfaction (and dissatisfaction) from comparing their attainments with those of others. As has been shown here, objective attainments like money and position seem to be relevant standards for comparing self with others. Selfreferent subjective success is also based on objective attainments, but the relationship is much smaller.

We conclude that it is indispensable to assess subjective success in career research, because objective success is only a vague proxy to subjective experiencing. Subjective success is a major aim of people's working life. It is not only a desirable state, but it may be also important for a person's objective attainments. Lacking subjective success can lead to disappointment, and eventually also to motivational deficits, to stress, burn-out and/or physical symptoms. The experience of high subjective success, in contrast, may also instigate motivational forces that eventually even lead to more objective success (Boehm and Lyubomirsky 2008; Hall 2002; Hall and Chandler 2005; Marks and Fleming 1999).

In a recent study we have shown that there is a positive feedback cycle between subjective and objective success (Abele and Spurk 2009b). We analyzed the longitudinal relationship between objective success (money, status) and subjective success (self-referent: job satisfaction; other-referent: comparison with former fellow students) and found that objective success influenced both the initial level and the changes of other-referent subjective success, but it had no influence on self-referent subjective success. Most importantly, both measures of subjective success and both their initial levels and their changes over time had strong influences on the changes in objective success. People who felt successful (both self-referent and other-referent) showed stronger increases in salary and status than people who did not feel successful.

Recommendations Career researchers interested in the dynamics of career success are well advised to operationalize objective career success with multiple measures (salary, position/status, promotions). They should also collect data on the employment context as well as on the career stage their respondents are in because only then can objective career success measures be adequately interpreted. Regarding subjective success career researchers are also well advised to take multiple measures of both self-referent success (job satisfaction, career satisfaction) and of other-referent success because the two capture slightly different areas of subjective success; and because they are both important as 
motivators for further - objective and subjective - success development.

\section{Executive summary}

The aim of the present paper is twofold. We first give an overview of the complex construct of career success with its "objective" (real attainments) and "subjective" (perceived attainments) components and with the different methodologies of measuring them ("subjectivist" vs. "objectivist" approaches). Secondly, we show that the interrelationship between the different facets of career success varies with the employment context (private-company-employed vs. stateemployed vs. self-employed).

The construct of career success is multifaceted and can be separated into a subjective and an objective component (Hughes 1937; Heslin 2005; Ng et al. 2005). Taking, for instance, income and promotions as central indicators of career success can be criticized because these indicators are dependent on labor-market conditions, occupational sector, organizations, and education. However, subjective components of career success are less influenced by these factors. Subjective career success can be separated into "self-referent" and "other-referent" subjective success. In self-referent subjective success an individual compares his/her career relative to personal standards and aspirations. For example, job satisfaction or career satisfaction are taken as criteria (Greenhaus et al. 1990). In other-referent subjective success an individual compares his/her career relative to a social standard, for instance a reference group, a reference person or a social norm (Abele and Wiese 2008; Heslin 2005).

Quantitative approaches for the measurement of objective and subjective career success are also called "objectivist," i.e., the researcher has his/her own impression of how career success is conceptualized and individual values have to be measured. Another approach that is also called "subjectivist" accounts for the fact that every individual has his/her own subjective meaning of career success (Arthur et al. 2005; Dries et al. 2008; Savickas 2005). Within this "subjectivist" approach the meaning of career success varies across people, employment contexts, occupations, age groups, and cultures. "Objectivist" and "subjectivist" approaches are not mutually exclusive but can complement one another.

A number of studies report positive correlations between objective career success and career satisfaction (Judge et al. 1995; Richardsen et al. 1997; Raabe et al. 2007; Schneer and Reitman 1993). Some studies show positive correlations between objective success and other-referent subjective success (Abele and Wiese 2008; Kirchmeyer 1998; Turban and Dougherty 1994). However, findings on the relationship between objective career success and job satisfaction are equivocal (no relationship: Judge et al. 1995; Richardsen et al. 1997; positive relationship: Judge et al. 1999b; Cable and DeRue 2002). Generally, meta-analyses reveal moderate relationships between objective and subjective career success (Dette et al. 2004: $\rho_{\text {est }}=0.28 ; \mathrm{Ng}$ et al. 2005: $\rho_{\text {est }}=0.30$ ). Furthermore, the study by Dette et al. (2004) revealed a large heterogeneity of results suggesting that there are further factors influencing the relationship between objective and subjective success.

To test the assumption that the size of the relationship between objective and subjective career success varies with the context (i.e., employment context), we analyzed data from a large sample of professionals working in the private sector, in the public sector, or that are self-employed. The sample comprised 510 women and 715 men (mean age 37 years) with degrees in law, medicine, arts and humanities, natural sciences, economics, engineering, and teaching. Indicators for objective career success were income and position (i.e., leadership position yes/no; project responsibility yes/no; permission to delegate work yes/no), indicators for subjective career success were job and career satisfaction (self-referent subjective success) and a scale comprised of three single comparison items (other-referent subjective success).

Our findings show that objective success and subjective success are more closely related in the private and selfemployment sectors than in the public sector. Moreover, the interrelationship between objective and subjective success varies with the specific subjective success measure chosen. It is stronger for other-referent subjective success than for self-referent subjective success. In summary, employment context and the type of subjective success measure moderate the relationship between objective and subjective career success. Conclusions regarding the measurement of career success as well as regarding the relevance of subjective success for studying occupational careers are drawn.

\section{Kurzfassung}

Der Beitrag verfolgt zwei Zielsetzungen. Erstens geben wir einen Überblick über das vielschichtige Konstrukt des Berufserfolgs und erläutern die verschiedenen Konnotationen von „objektivem“ (tatsächliche Errungenschaften) und „subjektivem“ (wahrgenommene Errungenschaften) Erfolg. Außerdem gehen wir auf verschiedene Möglichkeiten der Messung von Berufserfolg ein (,subjektivistische“ vs. „objektivistische“ Ansätze). Zweitens belegen wir empirisch anhand einer Stichprobe von Hochschulabsolventen, dass der Zusammenhang zwischen subjektivem und objektivem Berufserfolg kontextspezifisch (Privatwirtschaft vs. öffentlicher Dienst vs. Selbständigkeit) variiert. 
Das Konstrukt des Berufserfolgs ist facettenreich und kann in eine subjektive und objektive Komponente aufgeteilt werden (Hughes 1937; Heslin 2005; Ng et al. 2005). Die Verwendung von z. B. Gehalt und Beförderungen als Indikatoren von Berufserfolg kann aber kritisiert werden, da diese von Arbeitsmarktbedingungen, vom Berufsfeld, von der Organisation sowie vom Bildungsniveau abhängt. Subjektive Indikatoren des Berufserfolgs sind von diesen Faktoren weniger beeinflusst. Subjektiver Berufserfolg kann wiederum in sogenannten ,self-referent“ versus „other-referent" subjektiven Erfolg unterteilt werden. Beim „selbstbezogenen“ subjektiven Berufserfolg liegt der Referenzpunkt für die Einschätzung des Erfolgs innerhalb der eigenen Person, d. h. man beurteilt den eigenen Berufserfolg in Bezug auf eigene Standards, z. B. Laufbahnzufriedenheit (Greenhaus et al. 1990) oder Arbeitszufriedenheit. Beim ,auf andere bezogenen“ subjektiven Berufserfolg liegt der Referenzpunkt der Beurteilung außerhalb der eigenen Person, d.h. man vergleicht eigene Errungenschaften mit denen von anderen, z. B. stellt man Vergleiche mit relevanten anderen Personen an (Abele und Wiese 2008; Heslin 2005).

Quantitative Ansätze zur Messung von objektivem und subjektivem Berufserfolg können als „objektivistisch“ bezeichnet werden, d. h. der Forscher hat eine gewisse Vorstellung über die Konzeption von Berufserfolg und es soll die individuelle Ausprägung auf den entsprechenden Indikatoren festgestellt werden. Ein weiterer Ansatz, welcher auch als „subjektivistisch“ bezeichnet werden kann, berücksichtig die Tatsache, dass jedes Individuum die Bedeutung von Berufserfolg subjektiv konstruiert (Arthur et al. 2005; Dries et al. 2008; Savickas 2005). Innerhalb dieses Ansatzes ist davon auszugehen, dass die Bedeutung von Berufserfolg zwischen Menschen, Arbeitsformen, Berufen, Alterstufen und Kulturen variiert. „Objektivistische“ und „subjektivistische“ Ansätze zur Messung von Berufserfolg müssen sich dabei nicht zwangsläufig ausschließen, sondern können sich gegenseitig ergänzen.

Studien, welche sich mit dem Zusammenhang von verschiedenen Indikatoren des Berufserfolgs beschäftigen, finden meist positive Korrelationen zwischen verschiedenen Indikatoren des objektiven Berufserfolgs sowie der Karrierezufriedenheit (Judge et al. 1995; Richardsen et al. 1997; Raabe et al. 2007; Schneer und Reitman 1993) und dem ,auf andere bezogenen“ subjektiven Erfolg (Abele und Wiese 2008; Kirchmeyer 1998; Turban und Dougherty 1994). Dagegen gibt es keinen gesicherten Zusammenhang zwischen objektivem Berufserfolg und der Arbeitszufriedenheit (kein Zusammenhang: Judge et al. 1995; Richardsen et al. 1997; positiver Zusammenhang: Judge et al. 1999b; Cable und DeRue 2002). Generell berichten Metaanalysen von einem eher moderaten Zusammenhang zwischen objektivem und subjektivem Berufserfolg (Dette et al. 2004: $\rho_{\text {est }}=0,28 ; \mathrm{Ng}$ et al. 2005: $\rho_{\text {est }}=0,30$ ). Allerdings lässt eine hohe Heterogenität der einzelnen Effekte (Dette et al. 2004) darauf schließen, dass es Faktoren gibt, die noch genauer erforscht werden müssen.

Um die Annahme, dass der Zusammenhang zwischen objektivem und subjektivem Berufserfolg kontextspezifisch variiert (d. h. durch den Moderator „Art des Beschäftigungsverhältnisses“" vermittelt ist), zu überprüfen, analysierten wir Daten einer großen Stichprobe von Akademikern, die entweder in der Privatwirtschaft, im öffentlichen Dienst oder selbständig/freiberuflich arbeiten. Die Stichprobe setzt sich aus 510 Frauen and 715 Männern $(M=37$ Jahre) zusammen. Die Teilnehmer/innen besitzen Abschlüsse aus den Fakultäten Jura, Medizin, philosophische Fakultät, Naturwissenschaften, Wirtschafts- und Sozialwissenschaften, Ingenieurwissenschaften sowie Lehramt. Indikatoren für den objektiven Erfolg waren Gehalt und Position (Führungskraft ja/nein; Projektleitung ja/nein; Delegationsbefugnis ja/nein), Indikatoren für den subjektiven Erfolg waren Arbeits- sowie Karrierezufriedenheit (,selbstbezogener" subjektiver Erfolg) sowie eine Skala aus drei einzelnen Vergleichsurteilen (,auf andere bezogener“ Erfolg).

Es zeigte sich, dass der Zusammenhang zwischen subjektivem und objektivem Berufserfolg im öffentlichen Dienst kleiner ist als bei den beiden anderen Beschäftigungsformen. Außerdem variierte der Zusammenhang zwischen objektivem und subjektivem Erfolg je nach Art der Messung von subjektivem Erfolg. Objektiver Erfolg und subjektiver Erfolg als Vergleichsurteil korrelierten stärker als objektiver Erfolg und subjektiver Erfolg als Zufriedenheitsurteil. Insgesamt stellen also sowohl die Beschäftigungsform als auch die Art der Messung des subjektiven Erfolgs einen Moderator für den Zusammenhang von objektiven und subjektiven Berufserfolg dar. Folgerungen für die Messung von Berufserfolg und für die Bedeutung subjektiven Erfolgs in der Berufslaufbahn werden abgeleitet.

Acknowledgements The present research was supported by grants from the German Research Council to A. E. Abele (AB 45/8-1/2/4/6).

\section{References}

Abele, A.E.: The dynamics of masculine-agentic and femininecommunal traits: Findings from a prospective study. J. Pers. Soc. Psychol. 85, 768-776 (2003)

Abele, A.E., Spurk, D.: The longitudinal impact of self-efficacy and career goals on objective and subjective career success. J. Vocat. Behav. 74, 53-62 (2009a)

Abele, A.E., Spurk, D.: How do objective and subjective career success interrelate over time? J. Occup. Organ. Psych. 82, 803-824 (2009b)

Abele, A.E., Wiese, B.: The nomological network of self-management strategies and career success. J. Occup. Organ. Psych. 73, 490-497 (2008) 
Arthur, M.B., Rousseau, D.M.: The Boundaryless Career: A New Employment Principle for a New Organizational Era. Oxford University Press, New York (1996)

Arthur, M.B., Khapova, S.N., Wilderom, C.P.M.: Career success in a boundaryless career world. J. Organ. Behav. 26, 177-202 (2005)

Boehm, J.K., Lyubomirsky, S.: Does happiness promote career success? J. Career Assessment 16, 101-116 (2008)

Boudreau, J.W., Boswell, W.R., Judge, T.A.: Effects of personality on executive career success in the United States and Europe. J. Vocat. Behav. 58, 53-81 (2001)

Bozionelos, N.: Mentoring provided: Relation to mentor's career success, personality, and mentoring received. J. Vocat. Behav. 64, 24-46 (2004)

Briscoe, J.P., Hall, D.T.: The interplay of boundaryless and protean careers: Combinations and implications. J. Vocat. Behav. 69, 4-18 (2006)

Cable, D.M., DeRue, D.S.: The convergent and discriminant validity of subjective fit perceptions. J. Appl. Psychol. 87, 875-884 (2002)

Dette, E.D., Abele, A.E., Renner, O.: Zur Definition und Messung von Berufserfolg - theoretische Überlegungen und metaanalytische Befunde zum Zusammenhang von externen und internen Laufbahnerfolgsmaßen. Z. Personalpsychol. 3, 170-183 (2004)

De Vos, A., Soens, N.: Protean attitude and career success: The mediating role of self-management. J. Vocat. Behav. 73, 449-456 (2008)

Dries, N., Pepermans, R., Carlier, O.: Career success: Constructing a multidimensional model. J. Vocat. Behav. 73, 254-267 (2008)

Festinger, L.: A theory of social comparison processes. Hum. Relat. 7, 117-140 (1954)

Greenhaus, J.H., Parasuraman, S., Wormley, W.M.: Effects of race on organizational experiences, job performance evaluations, and career outcomes. Acad. Manage. J. 33, 64-86 (1990)

Gunz, H., Heslin, P.: Reconceptualizing career success. J. Organ. Behav. 26, 105-111 (2005)

Hall, D.T.: Careers in and out of Organizations. Sage, Thousand Oaks, CA (2002)

Hall, D.T., Chandler, D.E.: Psychological success: When the career is a calling. J. Organ. Behav. 26, 155-176 (2005)

Heslin, P.A.: Self- and other-referent criteria of success. J. Career Assessment 11, 262-286 (2003)

Heslin, P.A.: Conceptualizing and evaluating career success. J. Organ. Behav. 26, 113-136 (2005)

Hughes, E.C.: Institutional office and the person. Am. J. Sociol. 43, 404-413 (1937)

Judge, T.A., Cable, D.M., Boudreau, J.W., Bretz, R.D.: An empirical investigation of the predictors of executive career success. Pers. Psychol. 48, 485-519 (1995)

Judge, T.A., Higgins, C.A., Thoresen, C.J., Barrik, M.R.: The big five personality traits, general mental ability, and career success across the life span. Pers. Psychol. 52, 621-652 (1999a)

Judge, T.A., Thoresen, C.J., Pucik, V., Welbourne, T.M.: Managerial coping with organizational change: A dispositional perspective. J. Appl. Psychol. 84, 107-122 (1999b)

Kirchmeyer, C.: Determinants of managerial career success: Evidence and explanation of male/female differences. J. Manage. 24, 673-692 (1998)

Marks, G.N., Fleming, N.: Influences and consequences of well-being among Australian young people: 1980-1995. Soc. Indic. Res. 46, 301-323 (1999)

Martins, L.L., Eddleston, K.A., Veiga, J.F.J.: Moderators of the relationship between work-family conflict and career satisfaction. Acad. Manage. J. 45, 399-409 (2002)

Ng, T.W.H., Eby, L.T., Sorensen, K.L., Feldman, D.C.: Predictors of objective and subjective career success. A meta-analysis. Pers. Psychol. 58, 367-408 (2005)
Nicholson, N., De Waal-Andrews, W.: Playing to win: Biological imperatives, self-regulation, and trade-offs in the game of career success. J. Organ. Behav. 26, 137-154 (2005)

Olkin, I., Finn, J.D.: Correlations redux. Psychol. Bull. 118, 155-164 (1995)

Parsons, F.: Choosing a Vocation. Houghton Mifflin, Boston (1909)

Raabe, B., Frese, M., Beehr, T.A.: Action regulation theory and career self-management. J. Vocat. Behav. 70, 297-311 (2007)

Richardsen, A.M., Mikkelsen, A., Burke, R.J.: Work experiences and career and job satisfaction among professional and managerial women in Norway. Scand. J. Manag. 2, 209-218 (1997)

Savickas, M.: The theory and practice of career construction. In: Brown, S.S., Lent, R.W. (eds.) Career Development and Counselling: Putting Theory and Research to Work, pp. 42-70. Wiley, Hoboken, NJ (2005)

Schneer, J.A., Reitman, F.: Effects of alternate family structures on managerial career paths. Acad. Manage. J. 36, 830-843 (1993)

Schneer, J.A., Reitman, F.: The interrupted managerial career path: A longitudinal study of MBAs. J. Vocat. Behav. 51, 411-434 (1997)

Schwarz, N.: Self reports. How the questions shape the answers. Am. Psychol. 54, 93-105 (1999)

Seibert, S.E., Kraimer, M.L., Crant, J.M.: What do proactive people do? A longitudinal model linking proactive personality and career success. Pers. Psychol. 54, 845-874 (2001)

Spurk, D., Abele, A.E.: Who earns more and why? A multiple mediation model from personality to salary. J. Bus. Psychol. (in press) DOI 10.1007/s10869-010-9184-3 (2010)

Steiger, J.H.: Tests for comparing elements of a correlation matrix. Psychol. Bull. 87, 245-251 (1980)

Sullivan, S.E., Baruch, Y.: Advances in career theory and research: A critical review and agenda for further exploration. J. Manage. 35, 1542-1571 (2009)

Super, D.E.: A life-span, life-space approach to career development. In: Brown, D., Brooks, L. (eds.) Career Choice and Development: Applying Contemporary Theories to Practice, 2nd edn., pp. 197-261. Jossey-Bass, San Francisco, CA (1990)

Tabachnik, G.B., Fidell, L.S.: Using multi-variate statistics, 4th edn. Allyn \& Bacon, Needham Heights, MA (2001)

Turban, D., Dougherty, T.: Role of protégé personality in receipt of mentoring and career success. Acad. Manage. J. 37, 688-702 (1994)

Wayne, S.J., Liden, R.C., Kraimer, M.L., Graf, I.K.: The role of human capital, motivation and supervisor sponsorship in predicting career success. J. Organ. Behav. 20, 577-595 (1999)

Andrea E. Abele, full professor in Social Psychology at the University of Erlangen-Nuremberg. Studied psychology, sociology, and history at the University of Konstanz; Ph.D. at Konstanz; Habilitation at the University of Bielefeld; research stays in Britain and the US; editor and editorial board of several international journals; member of the executive committee of the interdisciplinary center for labor-market research at the University of Erlangen-Nuremberg.

Research topics: occupational career development; work and life satisfaction; fundamental dimensions of social judgment.

e-mail: abele@phil.uni-erlangen.de

Daniel Spurk, assistant at the Chair of Social Psychology at the University of Erlangen-Nuremberg. Studied psychology at the University of Erlangen-Nuremberg; currently completing his Ph.D. at the University of Erlangen-Nuremberg.

Research topics: career success, career development, self-efficacy. e-mail: daniel.spurk@ sozpsy.phil.uni-erlangen.de 
Judith Volmer, associate at the Chair of Social Psychology at the University of Erlangen-Nuremberg. Studied psychology at the University of Bielefeld, Ph.D. at the Universities of Braunschweig and Konstanz; research stays in the US; currently completing her Habilitation at the University of Erlangen-Nuremberg.

Research topics: Performance and career success; affect in organizations; leadership.

e-mail: judith.volmer@ sozpsy.phil.uni-erlangen.de 